Received 23 June; accepted 25 July 1977.

1 Anderson, J. S. in Defects and Transport in Oxides (eds Seltzer, M. S. \& Jaffee R. 1.) 24-54 (Plenum, New York, 1974).

Anderson, J. S. \& Tilley, R. J. D. in Surface and Defect Properties of Solids 3 (eds Roberts, M. W. \& Thomas, J. M.) 1-56 (Chemical Society, London, 1974). , A. N., Anderson, S. \& O'Keeffe, M. in A. Rev. mater. Sci.

4 Nanot, M., Queyreux, F., Gilles, J. C., Portier, R. \& Fayard, M. Mater. Res. Bull

Sguyen. N.. Studer, F., Groult, D., Choisnet, J. \& Raveau, B. J. Solid St. Chem.

- McConnell, J. D. M.. Hutchison, J. L. \& Anderson, J. S. Proc. R. Soc. A339, 1-12 (1974).

Tilley. R. J. D.J. Solid St. Chem. 7, 213-221 (1973).

g guchi, E. \& Tilley, R. J. D.J. Solid St. Chem. (in the press).

ursili, L. A., Hyde, B. G. \& O'Keefie, M. in Solid State Chemistry, N. B. S. spec. Pub, 364, (eds Roth, R. S. \& Schneider, S. J.) 197-204 (National Bureau Standards. Washington, 1972)

10 Young. K. F. \& Frederiske, H. P. R. J. phys. Chem. Ref. Data 2, 313-409 (1973).

Chernko, 1. M. \& Ivon, A. 1. Fiz. Tverd. Tela. 16, 2130-2133 (1974); English translation. Sov. Phys. Solid St. 16, 1391 (1975).

12 Lef kowitz. I., Dowell, M. B. \& Shiełds, M. A. J. Solid St. Chem. 15, 24-39 (1975).

13 Samara, G. A. \& Peercy, P. S. Phys. Rev. B7, $1131-1148$ (1973).

4 Emmenegger, F. P. \& Robinson, M. L. A. J. phys. Chem. Solids 29, 1673-1681 (1968)

Hyde, B. G. \& Tilley, R. J. D. J. phys. Chem. Solids 31, 1613-1619 (1970)

6 Tilley, R. J. D. J. Solid St. Chem. (in the press).

Bursill, L. A. Proc. R. Soc. A311, 267-290(1969)

eterson, G. E. in Treatise on Solid State Chemistry 2 (ed. Hannary, N. B.) $183-$ 236 (Plenum, New York, London, 1975).

19 Barker, A. S. in Ferroelectric's (ed. Weller, E. F.) 213-250 (Elsevier, Amsterdam, 1967).

\section{Crystal structure of rustumite}

Rustumite was first described by Agrell ${ }^{1}$ as $\mathrm{Ca}_{4} \mathrm{Si}_{2} \mathrm{O}_{7}(\mathrm{OH})_{2}$, space group $\mathrm{Cc}$ or $\mathrm{C} 2 / \mathrm{c}, a=7.62(5), b=18.55(5), c=$ $15.51(5) \AA, \beta=104^{\prime \prime} 20^{\prime}\left(10^{\prime}\right)$, with $Z=10$. The crystal structure we describe here, in space group $\mathrm{C} 2 / \mathrm{c}(R=11.3 \%$ for all data) gives, instead, an ideal formula $\mathrm{Ca}_{10}\left(\mathrm{Si}_{2} \mathrm{O}_{7}\right)_{2} \mathrm{SiO}_{4} \mathrm{Cl}_{2}(\mathrm{OH})_{2}$, with $Z=4$. The important features of the completed structure are the presence of chlorine and of orthosilicate groups in addition to $\mathrm{Si}_{22} \mathrm{O}_{7}$ groups.

The experimental intensity data, from a naturally occurring single crystal, comprised 2,100 independent reflections for layers $0.9, k, l\left(\sin ^{2} \theta<0.2\right)$ obtained with a Hilger and Watts $Y-190$ linear diffractometer and $\mathrm{Mo}-\mathrm{K} \alpha$ radiation, using the cell dimensions given by Agrell'. Of this data, 282 reflections were classed as 'unobserved', and were excluded from all further calculations.

Solution of the Patterson map was hindered by the large number of atoms in the unit cell $(\sim 150)$, permitting the detection of only four (or more)-multiple peaks, and the presence of subtranslations of $\sim a / 4, \sim b / 6$ and $\sim c / 6$ among the Patterson

Table 1 Rustumite-atomic parameters

\begin{tabular}{cccccc}
\hline \multicolumn{7}{c}{ Fractional coordinates } \\
$\left(10^{1}\right)$ & $z / c$ & $\AA^{2}\left(10^{2}\right)$ & $\begin{array}{c}\text { Occupancy } \\
\left(10^{2}\right)\end{array}$ \\
Atom & $x / a$ & $y / b$ & $c, 498(2)$ & $95(4)$ & $98(1)$ \\
$\mathrm{Ca}(1)$ & $2,582(4)$ & $3,520(1)$ & $2,498(2)$ & $96(4)$ & $97(1)$ \\
$\mathrm{Ca}(2)$ & $4,399(4)$ & $3,024(1)$ & $6,192(2)$ & $95(4)$ & $96(1)$ \\
$\mathrm{Ca}(3)$ & $5,760(4)$ & $2,068(1)$ & $4,039(2)$ & $95(4)$ & $98(1)$ \\
$\mathrm{Ca}(4)$ & $3,298(4)$ & $232(2)$ & $4,017(2)$ & $102(4)$ & $98(1)$ \\
$\mathrm{Ca}(5)$ & $3,106(4)$ & $5,148(1)$ & $3,964(2)$ & $93(4)$ & $97(1)$ \\
$\mathrm{Si}(1)$ & $4,420(5)$ & $6,319(2)$ & $5,614(2)$ & $76(5)$ & $98(1)$ \\
$\mathrm{Si}(2)$ & $3,692(5)$ & $1,340(2)$ & $5,643(2)$ & $83(5)$ & $99(1)$ \\
$\mathrm{O}(1)$ & $3,349(12)$ & $3,786(5)$ & $4,161(6)$ & $99(16)$ & $93(2)$ \\
$\mathrm{O}(2)$ & $4,782(12)$ & $1,759(5)$ & $6,518(6)$ & $96(15)$ & $98(2)$ \\
$\mathrm{O}(3)$ & $4,318(12)$ & $523(5)$ & $5,559(6)$ & $118(15)$ & $98(2)$ \\
$\mathrm{O}(4)$ & $4,629(12)$ & $5,760(5)$ & $1,594(6)$ & $95(15)$ & $97(2)$ \\
$\mathrm{O}(5)$ & $3,503(13)$ & $1,770(5)$ & $4,725(6)$ & $110(17)$ & $89(2)$ \\
$\mathrm{O}(6)$ & $3,767(13)$ & $6,870(5)$ & $4,777(6)$ & $105(16)$ & $93(2)$ \\
$\mathrm{O}(7)$ & $4,236(13)$ & $3,277(5)$ & $1,516(6)$ & $136(16)$ & $98(2)$ \\
$\mathrm{O}(8)$ & $3,168(13)$ & $4,778(5)$ & $2,481(6)$ & $107(15)$ & $97(2)$ \\
$\mathrm{O}(9)$ & $3,695(13)$ & $4,476(5)$ & $429(6)$ & $119(16)$ & $94(2)$ \\
$\mathrm{O}(10)$ & $2,384(6)$ & $2,961(2)$ & $7,458(3)$ & $54(6)$ & $204(2)$ \\
$\mathrm{O}(11)$ & $560(14)$ & $5,881(5)$ & $3,535(6)$ & $123(17)$ & $91(2)$ \\
$\mathrm{Si}(3)^{*}$ & $1 / 2$ & $5,276(3)$ & $1 / 4$ & $82(8)$ & $97(2)$ \\
\hline
\end{tabular}

Estimated standard deviations applicable to the least significant digits are given in parentheses.

${ }^{*} \mathrm{Si}(3)$ is in the special position $4 \mathrm{e}$ of $\mathrm{C} 2 / \mathrm{c}$, while all other atoms occupy general (8f) positions.

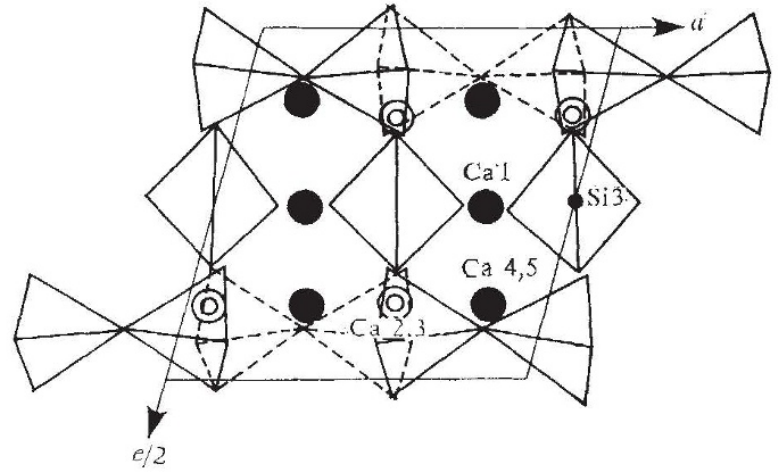

Fig. 1 Rustumite- $(\mathrm{O} 10)$ projection of one half of the unit-cell. The $\mathrm{Si}_{2} \mathrm{O}_{7}$ and $\mathrm{SiO}_{4}$ groups are indicated as polyhedra. The Ca atoms overlap in pairs: $1\left(\mathrm{Cal}, \mathrm{Cal}^{\prime}\right),(\mathrm{Ca} 4, \mathrm{Ca} 5) ; 0,(\mathrm{Ca} 2$, Ca3).

peaks. Nevertheless, an initial structure was established in the space group $\mathrm{Cl}$ by double superposition using two multiple peaks as shift vectors ${ }^{2}$ and consideration of the vector subsystem ${ }^{3}$.

In the course of refinement by the usual Fourier methods, as the remaining atoms of the structure appeared, the presence of first the twofold axis and finally the $c$-glide became obvious. The final solution in the space group $\mathrm{C} 2 / \mathrm{c}$, refined by block diagonal least squares using all of the observed reflections except 171 which showed especially poor agreement between $F_{o}$ and $F_{c}$, gave the parameters of Table 1 . At this stage $R$ was $7.4 \%$ for the data included in least squares ( $11.3 \%$ over all observed data).

In the asymmetric unit it is easy to pick out, apart from the five $\mathrm{Ca}$ atoms, an $\left(\mathrm{Si}_{2} \mathrm{O}_{7}\right)^{6-}$ group (involving $\mathrm{Sil}$ and $\mathrm{Si} 2$ ) and an $\left(\mathrm{SiO}_{4}\right)^{4-}$ group involving $\mathrm{Si3}$ on a twofold axis (Fig. 1), leaving only $\mathrm{O} 10$ and $\mathrm{O} 11$. The atom $\mathrm{O} 10$ yields a peak in the electron density maps comparable in size with $\mathrm{Si} 3$, gives an occupancy factor (refined as oxygen) of $\sim 2.0$ in least squares refinement and has no nearest-neighbour $\mathrm{Ca}$ atom closer than $2.75 \AA$, all consistent with this atom being $\mathrm{Cl}$. Bogomolov and Organova (personal communication) have given analytical data for chloride in rustumite.

Whereas all other $\mathrm{O}$ atoms, including $\mathrm{O} 10$, are four-coordinate, O11 has only three $\mathrm{Ca}$ nearest neighbours $(\mathrm{Ca}-\mathrm{O}, 2.33-2.37 \AA)$ all to one side of it, clearly allowing completion of its tetrahedral coordination by a hydrogen atom. Therefore, although there is no clear evidence for the $\mathrm{H}$ atom in the electron density or difference maps, $\mathrm{O} 11$ can reasonably be regarded as a hydroxyl group to give the formula $\mathrm{Ca}_{5}\left(\mathrm{Si}_{2} \mathrm{O}_{7}\right)\left(\mathrm{SiO}_{4}\right)_{0.5} \mathrm{Cl}(\mathrm{OH})$ for the formula of the assymetric unit (eight per cell) of rustumite. The cell contents are then $\mathrm{Ca}_{40} \mathrm{Si}_{20} \mathrm{O}_{72} \mathrm{Cl}_{8}(\mathrm{OH})_{8}$ compared with $\mathrm{Ca}_{40} \mathrm{Si}_{20} \mathrm{O}_{70}(\mathrm{OH})_{20}$ from Agrell's formula.

We thank Professor H. F. W. Taylor for bringing this problem to our attention and the SRC for a grant to V.V.I.

\section{R. A. HowIE \\ V. V. ILYUKHIN*}

Department of Chemistry,

University of Aberdeen,

Meston Walk,

Aberdeen, UK

Received I July; accepted 28 July 1977.

* Permanent address: Institute of Crystallography, Academy of Science, Moscow, USSR.

1 Agrell, S. O. Min Mag. 34, 1-is (1965). Russian. Institute of Applied Physics, Academy of Science (Moldavia), U.S.S.R., Kishinev, 1972). 3 Kuz'min, E. A.. llyukhin, V. V. \& Petrunina, A. A. The Method of Vector Subof Science (Ukraine), U.S.S. R., Kiev, 1976). 